Article

\title{
Bio-Inspired Proanthocyanidins from Blueberries' Surface Coating Prevents Red Blood Cell Agglutination on Urinary Silicon-Based Catheters
}

\author{
Viviana Orozco-Fernández ${ }^{1,2,+}$, Sofía Gómez-Solano ${ }^{1,2,+}$, Jennifer Calderón ${ }^{2}$, José Vega Baudrit ${ }^{2,3}$ (D), \\ Klaus Rischka ${ }^{4}$ and Yendry Corrales-Ureña ${ }^{1, *(D)}$
}

1 Centro de Investigación y Extensión en Materiales, Escuela de Ciencia e Ingeniería de los Materiales, Instituto Tecnológico de Costa Rica, Cartago 159-7050, Costa Rica; orozcofernandezv@gmail.com (V.O.-F.); sofiags06@gmail.com (S.G.-S.)

2 National Laboratory of Nanotechnology, National Center of High Technology (LANOTEC-CeNAT-CONARE), Pavas 1174-1200, Costa Rica; jennifercn14@gmail.com (J.C.); jvegab@gmail.com (J.V.B.)

3 Laboratory of Polymers (POLIUNA), National University of Costa Rica (UNA), Heredia 86-3000, Costa Rica

4 Department of Adhesive Bonding Technology and Surfaces, Fraunhofer Institute for Manufacturing Technology and Advanced Materials (IFAM), Wiener Street 12, 28359 Bremen, Germany; klaus.rischka@ifam.fraunhofer.de

* Correspondence: yendry386@hotmail.com

+ Both authors contributed equally to this work.

check for

updates

Citation: Orozco-Fernández, V.; Gómez-Solano, S.; Calderón, J.; Vega Baudrit, J.; Rischka, K.; Corrales-Ureña, Y. Bio-Inspired Proanthocyanidins from Blueberries' Surface Coating Prevents Red Blood Cell Agglutination on Urinary Silicon-Based Catheters. Coatings 2022, 12, 172. https://doi.org/ 10.3390/coatings12020172

Academic Editor: Shinn-Jyh Ding

Received: 9 December 2021

Accepted: 19 January 2022

Published: 29 January 2022

Publisher's Note: MDPI stays neutral with regard to jurisdictional claims in published maps and institutional affiliations.

Copyright: (C) 2022 by the authors. Licensee MDPI, Basel, Switzerland. This article is an open access article distributed under the terms and conditions of the Creative Commons Attribution (CC BY) license (https:// creativecommons.org/licenses/by/ $4.0 /)$.

\begin{abstract}
Thrombosis can cause the occlusion of implantable medical devices, leading to the rejection of the device and subsequent mortality. Thrombosis is primarily induced by red blood aggregation and coagulation. The administration of anticoagulant drugs is generally used as a treatment to avoid these processes. Adverse effects such as bleeding in the event of an anticoagulant overdose, osteoporosis associated with prolonged use, hypersensitivity, and hives have been reported. New strategies such as biomolecule surface functionalization have recently been studied to overcome these problems. In this study, we report a novel coating composed of polydopamine (PDA) and proanthocyanidins (PACs) from blueberry extract to avoid red blood aggregation in short-term use medical devices such as silicone catheters. We showed that PDA formed stable films on silicone surfaces and PACs could be immobilized on PDA layers using laccase as a catalyst. The PDAPACs films decreased surface hydrophilicity, increased surface roughness, and decreased plasma protein adsorption. The films were stable in phosphate buffer saline (PBS) and cell culture media. Furthermore, red blood cell adsorption and aggregation decreased. These effects are attributed to changes in the membrane fluidity that influences adhesion, the steric hindrance of the layers, and the low adsorption of plasma proteins on the PAC layer.
\end{abstract}

Keywords: implantable medical devices; thrombosis; red blood cell morphology; polydopamine films; agglutination; blueberry; urinary infections; proanthocyanidins

\section{Introduction}

The use of medical grade silicone has increased over the years, and its market value is projected to reach USD 16.04 billion by 2022, at a compound annual growth rate of $6.1 \%$ between 2017 and 2022 [1]. However, blood-contact silicone-based devices present a significant challenge due to their hydrophobic nature, since they promote the adsorption of nonspecific proteins, leading to platelet adhesion and the eventual formation of thrombi, which can cause blood flow obstruction and facilitate bloodstream infections, one of the leading causes of patient death [2,3]. Thrombi can also migrate to pulmonary circulation, causing a pulmonary embolism [4]. Venous thromboembolism is a global problem, with about 10 million cases annually, representing the third most crucial vascular disease after myocardial infarction and cerebrovascular events [5]. Thrombus formation is a common 
cause of failure of medical devices exposed to blood; it is believed that the rapid adsorption of plasma proteins on artificial surfaces initiates thrombus formation, as they provide continuous stimuli for platelet adhesion and activation [6,7]. Virchow's triad describes the three main conditions for medical device-induced thrombosis to occur: blood hypercoagulability, hemodynamic factors, and medical device materials. In medical devices, the amount and conformation of adsorbed plasma proteins depend on the material's surface properties, such as wettability, surface charge, chemistry, and topography [8].

The interaction of plasma proteins with artificial surfaces activates an intrinsic clotting pathway known as contact activation, which occurs through three serine proteinases and non-enzymatic cofactors, von Willebrand factor (vWF), immunoglobulins, and complement proteins, leading to complex protein-biomaterial and protein-protein interactions [8,9]. Circulating blood platelets irreversibly bind to adsorbed proteins through highly expressed receptors, including integrin membrane glycoprotein (GP) and the GPIb and GPIIb-IIIa $(\alpha \operatorname{Ilb} \beta 3)$ complexes bind to fibrinogen, one of the first plasma proteins to be deposited on artificial surfaces, as well as fibronectin, vitronectin, and vWF [6,7]. Red blood cells (RBC) passively adhere to proteins adsorbed on the material and contribute to platelet activation by releasing a low molecular weight compound that acts as a platelet agonist identified as adenosine diphosphate (ADP) $[7,10,11]$. It is believed that fibrinogen is the most potent aggregator of RBCs in plasma, while some studies describe the enhancement of fibrinogen-induced RBC aggregation by albumin [6,7].

The techniques historically used to prevent thrombosis include the administration of anticoagulant drugs such as heparin or warfarin and acetylsalicylic acid, which inhibit platelet aggregation [11-13]. Although oral anticoagulants have been used to prevent thrombosis, they cause adverse effects such as fever and bleeding, among others [13-15]. To reduce the side effects derived from the oral consumption of anticoagulants, alternatives such as the creation of venous catheters with anticoagulant coatings have been proposed [16]. Even so, these are commonly used in conjunction with oral or injectable coagulants prophylactically to increase their effectiveness and reduce the risk of bleeding and clot formation at the catheter site [17]. Another recent modification of catheters involves superhydrophilicity of their surface, which prevents RBC adhesion [18]. As therapeutic measures, other mechanisms have been developed, such as filters designed to collect the thrombi and experimental drugs injected into the bloodstream that have the capacity to undo the thrombi [19]. Various studies have linked the consumption of polyphenols in the diet with low platelet activation induced by oxidative stress due to the high oxidative activity of these compounds [20,21]. Grape seed extracts contain polyphenols such as gallic acid, falvan-3-ols, and proanthocyanidins (PACs) that interact with various platelet activation pathways [22]. Nevertheless, the consumption of PACs, anthocyanins, and tannins has produced inconsistent effects in investigations on platelet aggregation, showing, in some cases, the inhibition of ADP-induced platelet aggregation and the formation of arterial thrombi [23], with no effect on platelet aggregation, or even an increase in ADP-induced platelet aggregation by almost $10 \%$ [21].

A more recent strategy to introduce plant polyphenols such as PACs in devices in contact with blood is the direct impregnation of polyphenols on the polymer's surface $[24,25]$. Recently, a new platelet repellent surface was reported. Tannic acid (TA) was used to represent the polyphenol and the $\mathrm{Fe}^{3+}$ ion as a metal cross-linking agent through the metal coordination interaction ( $\mathrm{Fe}^{3+}$ ions)-AT. The results showed lower platelet adhesion events on the silicon substrates with the coating compared to the original substrate, demonstrating that platelet adhesion on the Fe-TA film surfaces can be effectively repelled. Furthermore, the repellent effect was significantly better than that of the more commonly used poly (ethylene glycol) (PEG) [26].

Proanthocyanidins (PACs) are the primary polyphenols present in berries. PACs are biopolymers of flavanols-3 and are also known as condensed tannins [27]. In this study, a commercial silicone-coated catheter is functionalized with the PAC from blueberry from Vaccinium corymbosum. For this purpose, the catheter surface must be modified or activated 
before further functionalization due to the low stability of the PACS on the silicone surface. Polydopamine (PDA) has proven itself to be a feasible coating for catheters and acts as a platform for different binding agents $[27,28]$. PDA is a highly versatile, bio-inspired material due to its catechol and amine-adhesive functional groups, which mimic the natural bioadhesion properties of the mussel $[29,30]$.

The immobilization of the PACs using laccase on the catheter-polydopamine surface is also studied. The laccase enzyme (polyphenol oxidase, EC 1.10.3.2) catalyzes various phenolic compounds such as PAC and polyphenols in aerated solutions [29]. In this study, an ethanolic extract was obtained and characterized by attenuated total reflection Fourier Transform infrared spectroscopy (FTIR), its polyphenol content was measured using the Folin-Ciocalteu method [31], and proanthocyanidins content was established using the butanol- $\mathrm{HCl}$ method [32]. The enzymatic reaction of the laccase from Trametes versicolor and the natural extract was evaluated using isothermal titration calorimetry (ITC). The formation of thin films on the catheter surface was studied by FTIR, contact angle, and atomic force microscopy (AFM). The FTIR, contact angle, and AFM analyses were performed again after washing the substrates with phosphate-buffered saline (PBS) and physiological medium for four hours; these washes were performed to characterize the stability of the coatings. We evaluated the effect of the coating on the agglutination of red blood cells on the surface by quantifying the number of plasma proteins and bovine serum albumin (BSA) adhering to the surface of the catheters using a BCA test [33], as well as by studying the adhesion of RBC after contact with a human blood solution for one hour and under shaking. We prepared a SYLGARD ${ }^{\mathrm{TM}} 184$ silicone elastomer model [Dow Corning., USA] to mimic the catheter surface and to measure the Young's Modulus of the cells adhered to the surface by AFM.

\section{Materials and Methods}

The extract was produced from Vaccinium Corymbosum blueberries (BerryTico brand, Costa Rica). The sterile Catheter FOLEYCATH ${ }^{\circledR}$ NR Latex Balloon, composed primarily of natural rubber latex with a silicone coating, was used. This product meets the conformities of BS EN 1616: 1997, ASTM F623, and MS1369: 1995. Dopamine hydrochloride (98\%, Sigma Aldrich, Darmstadt, Germany) was used to form the PDA film. The laccase enzyme from Trametes versicolor was purchased from Sigma Aldrich, Germany. 99.7\% Iron ammonium sulfate (III) (98.5\% Merck, Darmstadt, Germany), 99.8\% butanol, and 99.37\% iron oxide (III) (Sigma Aldrich, Darmstadt, Darmstadt, Germany) reagents were used to carry out the Folin-Ciocalteu method for polyphenol quantification and to carry out the butanol$\mathrm{HCl}$ assay to detect proanthocyanidins. Sodium acetate, acetic acid, and Tris-base were purchased from Sigma Aldrich, Germany. Voluntary donors donated the blood used in this research (Project protocols revised and approved by the ethical commission of the UCIMED Costa Rica, CEC-0488-2021).

\subsection{Blueberry Extract Preparation}

Frozen Vaccinium corymbosum blueberries were crushed using a mortar and pestle and then extracted using ethanol $(70 \%)$ at room temperature for eight hours. The supernatant liquid was filtered, and the filtration was concentrated under a vacuum by a rotary evaporator. The resulting solid extract was dried on the stove for five days at $45^{\circ} \mathrm{C}$.

\subsection{Extract Characterization}

\subsubsection{Total Polyphenol Content}

Solutions with a concentration of $400 \mu \mathrm{g} / \mathrm{mL}$ were prepared to perform a calibration curve. Each standard solution was prepared by mixing $0.25 \mathrm{~mL}$ of Folin-Ciocalteu reagent previously diluted with distilled water (1:10) with an aliquot of the tannic acid solution. Then, $0.85 \mathrm{~mL}$ of $\mathrm{Na}_{2} \mathrm{CO}_{3} \cdot 10 \mathrm{H}_{2} \mathrm{O}(20 \% \mathrm{~m} / \mathrm{v})$ solution was added to the mixture and placed in a $4 \mathrm{~mL}$ volumetric flask. The flask was filled with distilled water. The mixtures were incubated for $20 \mathrm{~min}$ at room temperature in the dark. After the reaction period, the 
absorbance of the solutions was measured at a wavelength of $735 \mathrm{~nm}$ in a Shimadzu UV-Vis spectrophotometer (model UV-1800, Shimadzu Corporation, Kyoto, Japan). Three replications were performed with three independent replicas.

\subsubsection{Butanol-HCl Assay for Detection of Proanthocyanidins}

Extract samples were dissolved in methanol to obtain $1 \mathrm{~mL}$ of solution with a concentration of $0.1 \mathrm{mg} / \mathrm{mL}$ of polyphenols (according to previous results of the Folin-Ciocalteu method for each extract sample) and then mixed with $6 \mathrm{~mL}$ of a butanol- $\mathrm{HCl}$ solution (95:5 $v / v)$, and $0.2 \mathrm{~mL}$ of iron reagent solution $\left(2 \% w / v \mathrm{NH}_{4} \mathrm{Fe}\left(\mathrm{SO}_{4}\right)_{2} 12 \mathrm{H}_{2} \mathrm{O}\right.$ in $\left.2 \mathrm{M} \mathrm{HCl}\right)$. The resulting solution was heated in a boiling water bath for $40 \mathrm{~min}$ and then cooled down to room temperature. The UV-Vis spectrum was recorded from 400 to $700 \mathrm{~nm}$. Proanthocyanidins were detected with a characteristic absorbance maximum around $550 \mathrm{~nm}$. For the specific detection of proanthocyanidins present in the extract, the method of Liu et al., 2007 was used, in which the proanthocyanidins were isolated and then quantified by means of a butanol- $\mathrm{HCl}$ assay through ultraviolet-visible spectrophotometry (UV-Vis).

\subsubsection{Attenuated Total Reflection Fourier Transform Infrared Spectroscopy (ATR-FTIR)}

A Nicolet 6700 ATR-FTIR spectrophotometer (Thermo Scientific, Waltham, MA, USA) was used, scanning through wavenumbers from 4000 to $400 \mathrm{~cm}^{-1}$ with a standard resolution of $0.09 \mathrm{~cm}^{-1}$ and a scanning speed of $32 \mathrm{~cm}^{-1} / \mathrm{s}$. The peak intensity ratios were calculated using the absorbance values.

\subsubsection{Isothermal Titration Calorimetry (ITC)}

ITC experiments were performed with a NanoITC2G (T. A. Instruments, New Castle, DE, USA). An extract solution of $15.3 \mathrm{mg} / \mathrm{mL}$ was titrated over a laccase solution of $0.1 \mathrm{mg} / \mathrm{mL}$. A volume of $1200 \mu \mathrm{L}$ solution was loaded in the cell and titrated with 19 titrant aliquots of $5 \mu \mathrm{L}$, the temperature was kept constant at $25 \pm 0.1{ }^{\circ} \mathrm{C}$ during the experiments, and the system was continuously stirred $(250 \mathrm{rpm})$ with the syringe. Blank experiments were carried out by titrating water on the extract and the laccase suspension on water. All experiments were carried out at least in triplicate.

\subsection{Catheter Surface Modification and Stability Test}

Catheter substrates of $1 \mathrm{~cm} \times 0.5 \mathrm{~cm}$ were introduced into $1.5 \mathrm{~mL}$ Eppendorf tubes containing $160 \mu \mathrm{L}$ of $0.5 \mathrm{mg} / \mathrm{mL}$ of dopamine hydrochloride in Tris Buffer $(\mathrm{pH} \mathrm{8.0)}$ for $30 \mathrm{~min}$ or $3 \mathrm{~h}$ to form PDA films. Then, the samples were gently rinsed with Milli-Q water. Then, $160 \mu \mathrm{L}$ of $30 \mathrm{mg} / \mathrm{mL}$ Vaccinium Corymbosum extract and $20 \mu \mathrm{L}$ of a $0.3 \mathrm{mg} / \mathrm{mL}$ solution of Lacasse enzyme sodium acetate ( $\mathrm{pH}$ 5.0) were added to the Eppendorf, and the reaction was carried out for $24 \mathrm{~h}$. Finally, the samples were gently rinsed with Milli-Q water. Figure 1 shows the samples preparation diagram. The stability test was performed by submerging the samples in phosphate buffer $1 \mathrm{mM}$ and physiological medium for $24 \mathrm{~h}$.

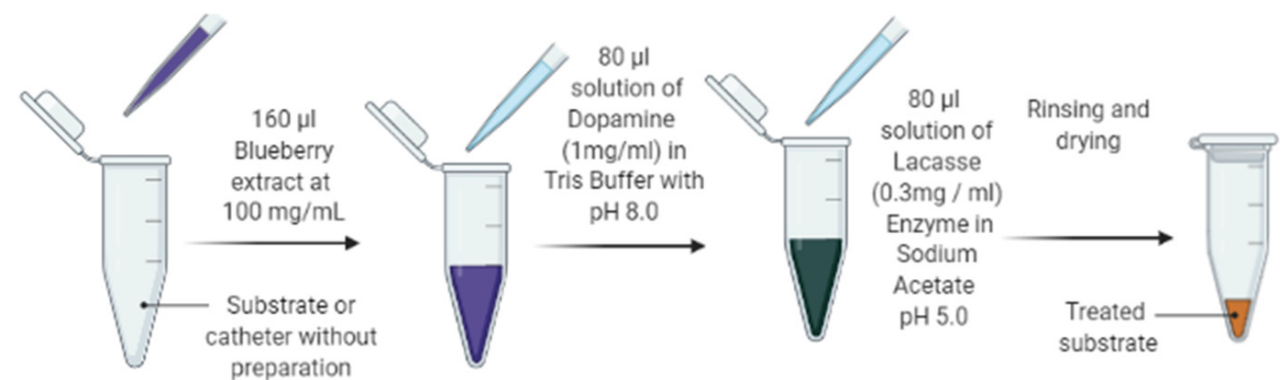

Figure 1. Scheme of the samples' functionalization protocol.

\subsection{Contact Angle Measurements}

The apparent water contact angles were measured using a goniometer (OCA15 Plus, Data Physics Instruments, Filderstadt, Germany) and applying the sessile drop technique. 
For each measurement, $10 \mu \mathrm{L}$ drops were formed using HPLC-grade water (Acros Organics, Geel, Belgium), and the subsequently reported contact angles were taken as an average of at least three measurements.

\subsection{Protein Adsorption Assay}

To make the calibration curve, diluted BSA standard solutions were prepared from the stock solution, a $100 \mu \mathrm{L}$ aliquot was taken from each solution and $1 \mathrm{~mL}$ of the BCA reagent was added; each standard was incubated for $10 \mathrm{~min}$ at $60^{\circ} \mathrm{C}$ in the oven, and the absorbance was measured at $562 \mathrm{~nm}$. For the treatment of substrates, a $250 \mu \mathrm{g} / \mathrm{mL}$ BSA (Sigma Aldrich, Darmstadt, Germany) solution was prepared, $400 \mu \mathrm{L}$ of BCA solution was added in each vial (prepared as shown in Section 3) and left to stand for three $h$, an aliquot of $100 \mu \mathrm{L}$ of each vial was taken and mixed with $1 \mathrm{~mL}$ of the BCA reagent (Sigma Aldrich, Darmstadt, Germany), each one was incubated for $10 \mathrm{~min}$ at $60^{\circ} \mathrm{C}$ in an oven, and the absorbance was measured at $562 \mathrm{~nm}$ in a Shimadzu UV-Vis spectrophotometer (model UV-1800, Shimadzu Corporation, Kyoto, Japan). Three replications were performed with three independent experiments. Plasma proteins were isolated by centrifugation of the two-times diluted blood in PBS at $5000 \mathrm{rpm}$. The supernatant diluted 45 times with PBS was used for the protein adsorption quantification analysis.

\subsection{Red Blood Cells' Agglutination on the Catheter Surface}

To evaluate effects on red blood cells' agglutination, the catheter was exposed to human blood for $30 \mathrm{~min}$. The application methodology of this experiment was formulated with reference to [33-35]. The procedure was performed on sterilized catheter fragments with a $1 \mathrm{~cm} \times 1 \mathrm{~cm}$ area (or substrate). Therefore, three replicates of each sample and three independent experiments were produced. The cells were fixed in Karnovsky solution (5\% glutaraldehyde, $4 \%$ paraformaldehyde, $0.1 \mathrm{M}$ phosphate buffer) for $15 \mathrm{~min}$. Then, they were dehydrated through an increasing gradient of 30\%, 50\%, 70\%, 90\%, 95\% v/v, and $100 \%$ ethyl alcohol for 15 min each. The samples' surfaces were imaged by SEM. A flat A model substrate was prepared using a SYLGARD ${ }^{\mathrm{TM}} 184$ silicone elastomer to determine the changes in the Young's modulus of cross-linked red blood cells adhered on the functionalized and non-functionalized surface substrate.

\subsection{Scanning Electron Microscopy (SEM)}

The samples were analyzed using a SEM JSM-5900 LV (JEOL, Tokyo, Japan), voltage $20 \mathrm{kV}$, pressure of $1 \times 10^{-4} \mathrm{~Pa}$. The samples were coated with a $5 \mathrm{~nm}$ gold layer by sputtering. The images were analyzed using Inca JEOL software.

\subsection{Amplitude-Modulated Atomic Force Microscopy (AFM)}

The substrates were dried under environmental conditions. The sample topography was analyzed using an AFM operated in tapping mode (Asylum Research, Santa Barbara, CA, USA) in air. Silicon probes (Nanosensors with Al-covered cantilever backsides) with a resonance frequency of $13 \mathrm{kHz}$ and force constant of $0.2 \mathrm{~N} / \mathrm{m}$ were used. Nanoscope software (version AR 16.26.229) was used to analyze the data. The cantilever's deflection and spring constant was calibrated before each measurement using the Thermal Get Real tool (tutorial https: / / www.youtube.com/watch? $\mathrm{v}=\mathrm{Wp}$-U5HXbMys, access on 9 December 2021). The data obtained during retraction were used to model and estimate the Young's modulus. The cells adhered to the surface after contact for one hour with the surface were fixed using Kartnosky and dehydrated using an ethanol series. The fitting of slope of the force-distance curve was performed using the Hertz model. Five cells per substrate were analyzed. Six substrates of each type-sample or control—were analyzed.

\section{Results}

A purple ethanolic extract from blueberries was obtained; the amount of solid extract obtained was $2.8 \mu \mathrm{g} / \mathrm{mg}$ of fresh blueberry and the amounts of quantified polyphenols and 
proanthocyanidins were $34 \mu \mathrm{g} /$ per $\mathrm{mg}$ of dried purple extract and $0.2 \mathrm{mg} / \mathrm{mg}$ of dried purple extract, respectively.

Figure 2a shows the FTIR spectra of the blueberry extract. The peak at $3361 \mathrm{~cm}^{-1}$ corresponds to the $\mathrm{O}-\mathrm{H}$ stretching vibrations of the $\mathrm{CH}_{2}-\mathrm{OH}$ groups, at $2935 \mathrm{~cm}^{-1}$ to the antisymmetric stretching vibrations $\mathrm{C}-\mathrm{H}$ of the $\mathrm{CH}_{2}$ groups, and the bending vibrations $\mathrm{C}-\mathrm{H}$ of the same functional group at $1408 \mathrm{~cm}^{-1}$. The peaks at 1640, 1275, and $1716 \mathrm{~cm}^{-1}$ are associated with the vibration of the $\mathrm{C}-\mathrm{C}$ bonds of the phenolic groups, $\mathrm{C}-\mathrm{O}$, and $\mathrm{C}=\mathrm{O}$ bonds of the aromatic groups, respectively. The peaks at 817 and $1050 \mathrm{~cm}^{-1}$ correspond to the $\mathrm{C}-\mathrm{O}$ stretching vibrations of the aromatic group -O- According to the FTIR spectra, peaks corresponding to the characteristic functional groups of phenolic compounds such as condensed tannins were observed in the extract spectra [36,37]. Figure $2 b$ shows the multiple injections of ITC enzyme kinetic data. The displacement, following each injection, of the horizontal baseline relative to the initial baseline $(\mathrm{dQ} / \mathrm{dt})$, is associated with an active enzyme, and this value is proportional to the enzyme velocity [38].

(a)

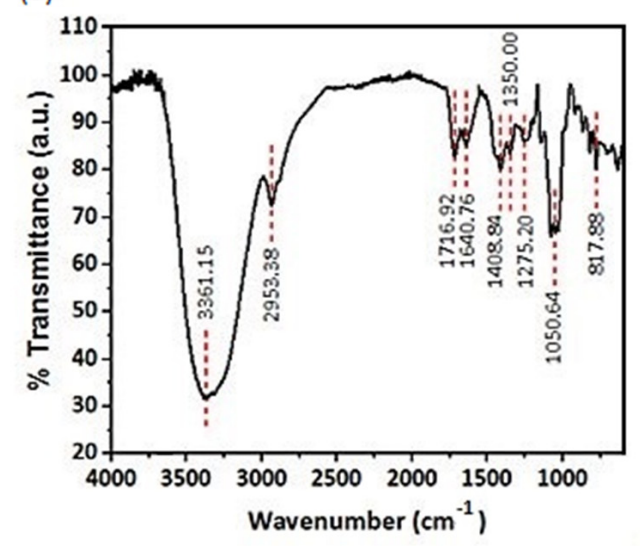

(b)

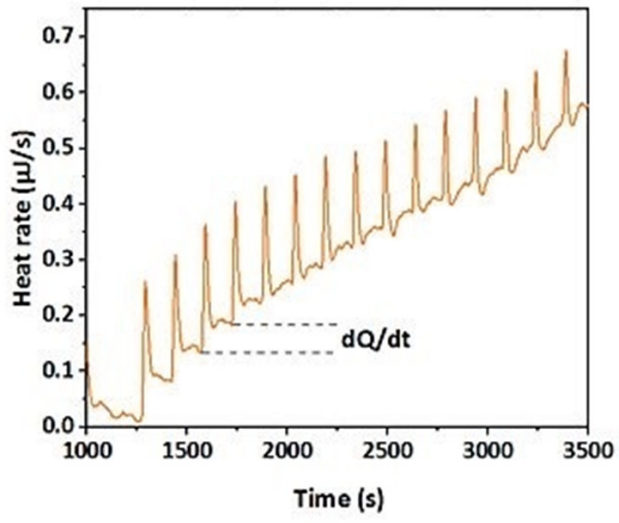

Figure 2. (a) ATR-FTIR spectra of the dried Vaccinium Corymbosum extract. (b) Multiple injections of ITC laccase enzyme kinetic data.

Figure 3a shows the extract, catheter, and dopamine FTIR spectra with their characteristic peaks highlighted. The silicone-coated catheter presents distinct peaks at $824 \mathrm{~cm}^{-1}$, $1097 \mathrm{~cm}^{-1}, 1737 \mathrm{~cm}^{-1}$, and $2960 \mathrm{~cm}^{-1}$, corresponding to the $\mathrm{Si}-\mathrm{C}$ bond of $\mathrm{Si}-\mathrm{CH}_{3}$ stretching vibrations, $\mathrm{Si}-\mathrm{O}, \mathrm{C}=\mathrm{O}$ bonds, and the stretching vibrations of the $\mathrm{CH}$ bonds of $\mathrm{CH}_{3}$ functional groups, respectively $[39,40]$. The dopamine spectra show peaks at 3340,1598, $1280 \mathrm{~cm}^{-1}$, corresponding to the symmetric stretch mode of $\mathrm{NH}_{2}$, the bending vibrations of $\mathrm{NH}_{2}$, and the $\mathrm{OH}$ stretching vibrations, respectively. The peaks at the 1315 and $1186 \mathrm{~cm}^{-1}$ bands correspond to the $\mathrm{O}-\mathrm{H}$ bending [41,42]. Figure 2 also shows the spectra of the functionalized catheter. The intensity decreases in the silicone represent peaks of 800 and $2900 \mathrm{~cm}^{-1}$, with the intensity of the bands close to 1100,1400 , and $3500 \mathrm{~cm}^{-1}$, suggesting a successful functionalization and film formation with PDA and PDA extract. Figure $3 b-d$ show a plot of the values obtained from the peak intensity correlation within $800 \mathrm{~cm}^{-1}$ in each spectrum, with their respective peaks close to $1000-1100,1400,2900 \mathrm{~cm}^{-1}$, and 3000 to $2500 \mathrm{~cm}^{-1}$, when the substrates were lightly washed with PBS, rinsed $24 \mathrm{~h}$ with PBS, and rinsed $24 \mathrm{~h}$ with medium, respectively. This correlation was calculated according to the following formula: (peak intensity $\left.\left(\mathrm{x} \mathrm{cm}^{-1}\right)\right) /\left(\right.$ Peak intensity $\left(800 \mathrm{~cm}^{-1}\right)$ ). 


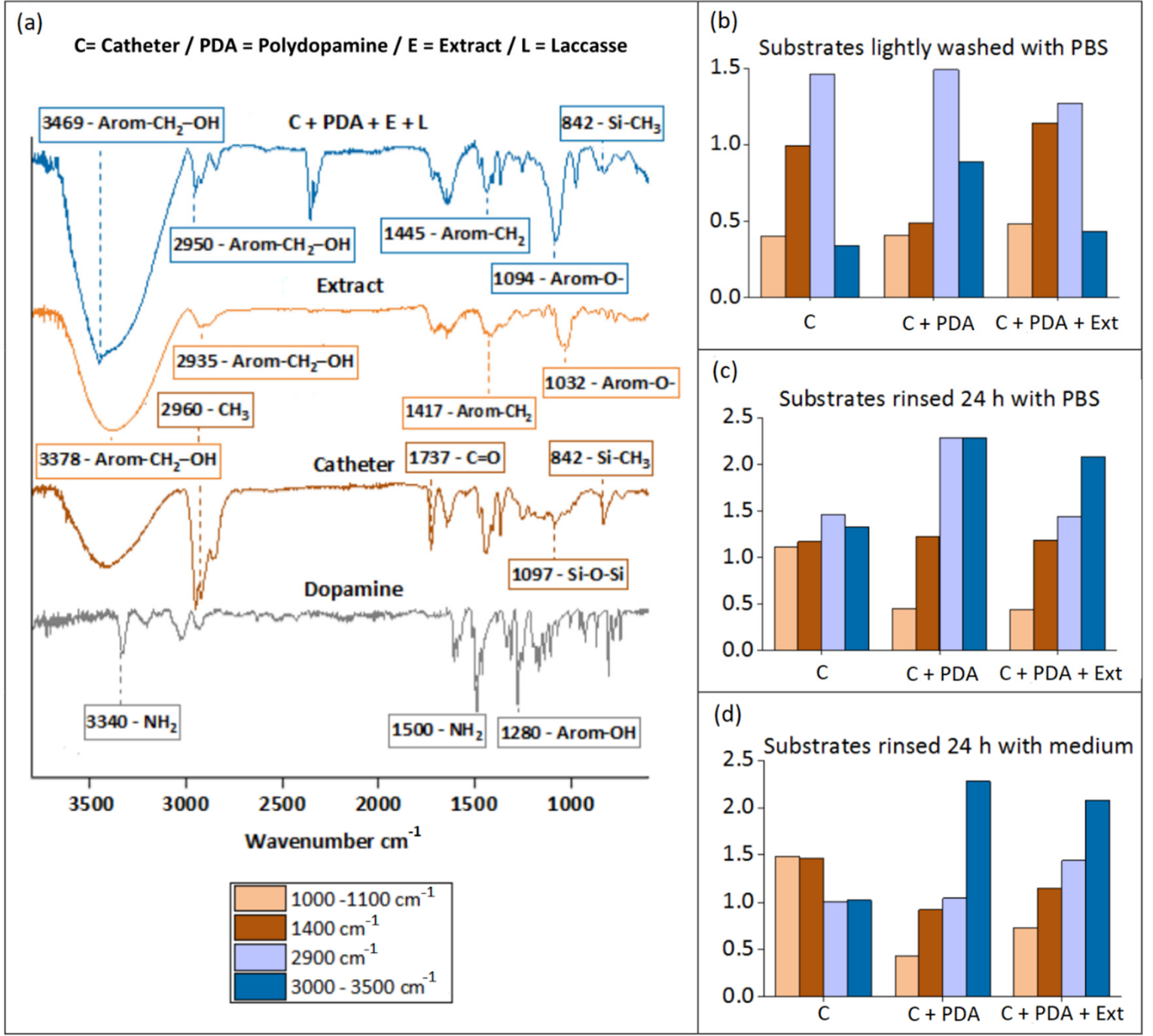

Figure 3. (a) FTIR and representative peaks and functional groups of dopamine hydrochloride, catheter, extract, and the catheter with the thin layer of PDA and extract. (b) Peak intensity correlation between $800 \mathrm{~cm}^{-1}$ of FTIR spectra of the pristine catheter/representative peaks when the substrates were lightly washed with PBS. (c) Peak intensity correlation between $800 \mathrm{~cm}^{-1}$ of each FTIR spectra/representative peaks when the substrates were rinsed for $24 \mathrm{~h}$ with PBS. (d) Peak intensity correlation between $800 \mathrm{~cm}^{-1}$ of each FTIR spectra/representative peaks close when the substrates were rinsed $24 \mathrm{~h}$ with physiological medium.

The greater values are attributed to the contribution of the aromatic- $\mathrm{CH}_{2}, \mathrm{OH}$, and $\mathrm{CH}_{2}$ groups, as highlighted in Figure 3 [43]. The greater intensity of the bands in the rinsed substrates may be due to the contribution of proteins present in the physiological medium, and to the elimination of contaminants on the surface that are not removed with light washing.

Figure $4 a, c$, show the AFM images of the pristine catheter surface in 2D and 3D, respectively; likewise, Figure $4 b, d$, show the surface of the functionalized catheter. When comparing the 2D images, it is not possible to observe changes due to the irregularities of the surface at the microscale. However, at the nanoscale and analyzing areas of $1 \mu \mathrm{m}$, the functionalized surface showed that there were significant changes in the root mean square roughness (RMS) [44,45]. An average RMS was $9.2 \mathrm{~nm}$ for the pristine catheter and $24.6 \mathrm{~nm}$ for the functionalized catheter, suggesting a thin layer formation due to an increase in roughness. Figure $4 \mathrm{c}$ shows a water drop on the pristine catheter and functionalized substrate surfaces. There is a reduction in the surface hydrophobicity and a decrease in the 
contact angle when the surface is coated with PDA; the change from $80^{\circ} \pm 4^{\circ}$ to $63^{\circ} \pm 3^{\circ}$ suggests PDA coating formation. The presence of the extract compounds on the surface is suggested by a further increase in the hydrophilicity of the surface with respect to that of the substrate functionalized only with PDA from $63^{\circ} \pm 3^{\circ}$ to $20^{\circ} \pm 3^{\circ}$. The aromatic $-\mathrm{OH}$ and aromatic-O groups could improve the affinity of the surface with the water and change its wettability [46]. To test the stability of the PDA-Ext coating, the functionalized surfaces were rinsed with PBS and physiological medium for $24 \mathrm{~h}$, the apparent contact angles on the surface were $40^{\circ} \pm 3^{\circ}$ and $16^{\circ} \pm 3^{\circ}$, respectively, the permanence in reducing wettability on the surface suggests that the coating is stable.

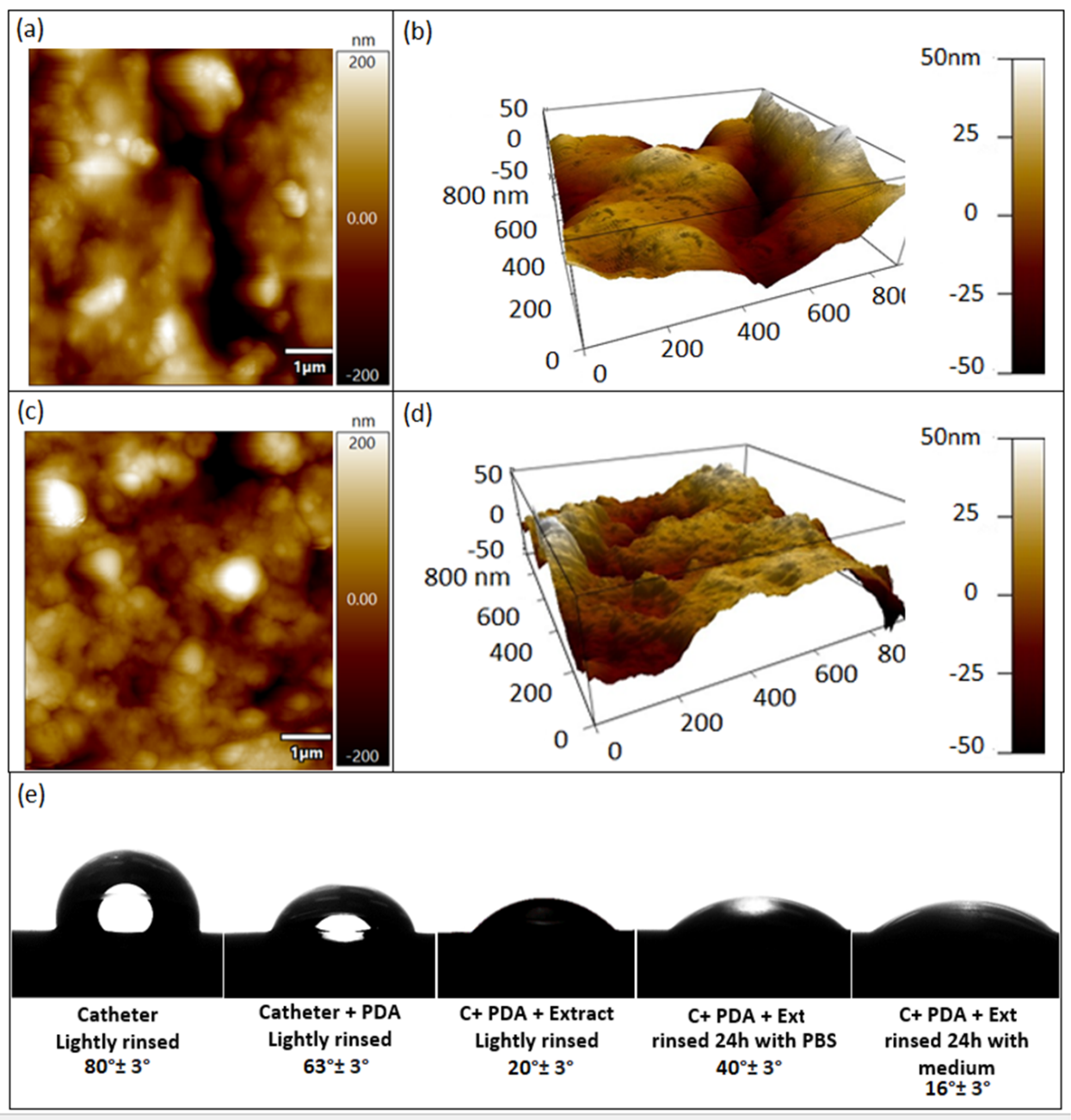

Figure 4. AFM images of $(\mathbf{a}, \mathbf{b})$ pristine catheter in 2D and 3D images, respectively; $(\mathbf{c}, \mathbf{d})$ the functionalized catheter; (e) photographs of $10 \mu \mathrm{L}$ drop of water on the pristine catheter and the functionalized catheter.

We performed a BCA test to quantify the amount of BSA and plasma proteins once the solution was exposed to samples of pristine catheter and catheter functionalized with the PDA-Ext; the initial BSA concentration was $0.250 \mathrm{mg} / \mathrm{mL}$ and, after contact with the surfaces, it was $0.187 \mathrm{mg} / \mathrm{mL}$ and $0.228 \mathrm{mg} / \mathrm{mL}$, respectively. This is the result of the amount of protein remaining in the solution supernatant. The difference in BSA concentrations shows that protein adsorption on the catheter surface functionalized with PDA-Ext was lower. This result may be due to the polymeric forms of tannins, such as macromolecular-condensed tannins, which exhibit greater steric hindrance, and their available reactive sites are widely separated; therefore, BSA protein would interact less with the surface due to steric effects [47]. Similar results were obtained for plasma proteins, as can be seen in Figure 5. 

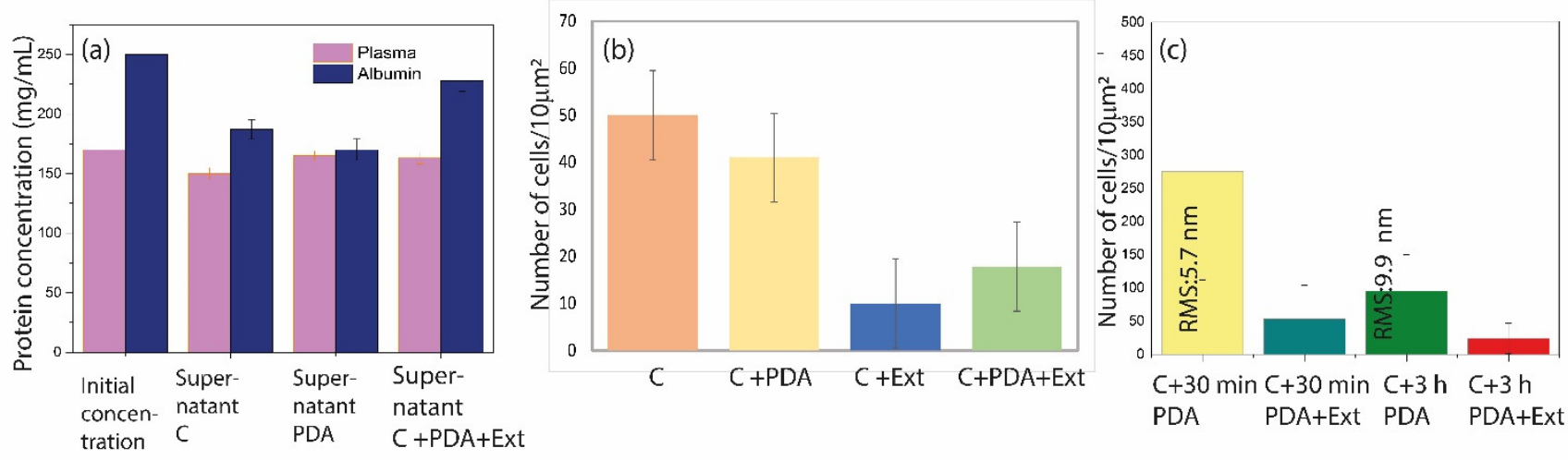

Figure 5. (a) Plasma protein and albumin adsorption quantification on the pristine catheter (called $\mathrm{C}$ in the graphic), C+ PDA and C + PDA + Ext surface. (b) Quantification of the number of RBC adhered to the pristine and functionalized catheter. (c) Quantification of the number of RBC adhered to the model PDMS surface in contact with the dopamine solution after $30 \mathrm{~min}$ and $3 \mathrm{~h}$ and next, in contact with extract for $24 \mathrm{~h}$.

BSA is used as a fouling agent to be adhered to surfaces and to be able to make a quantification of the adhesion of proteins to the surface. However, in the literature it is described that BSA can be an adhesion inhibitor agent. Increased surface roughness can increase dirt by trapping dirt in the valley formed on the surface of the membrane. Soiling can be trapped in the valleys of the membrane. In addition, the masking of the by the polymer chain during the membrane precipitation can also cause the fouling decrease by minimizing the nanocomposite membrane to $5 \%$ by weight due to the high concentration of antifouling filler on the surface of the membrane [48].

In Figure $5 b$, to determine the amount of red blood cells adhered to the catheter alone and to the catheter modifying the surface, SEM images were taken; the red blood cell count was performed by counting an area of $10 \mu \mathrm{m} \times 10 \mu \mathrm{m}$. Figure $5 \mathrm{c}$ shows the amount of RBC adhered on the surface of PDA-Ext films with different PDA thicknesses. The roughness of the PDA film formed on the PDMS surface after $30 \mathrm{~min}$ and $3 \mathrm{~h}$ in contact with the dopamine solution were $5.7 \mathrm{~nm}$ and $9.9 \mathrm{~nm}$, respectively.

As can be seen in the graph, the amount of RBC adhered to the surface in the PDA + extract samples decreased. While in contrast to what was found by Dang et al. 2015, it is observed that with a greater thickness of PDA, the amount of RBC that adheres is less. [49].

The changes in the roughness of the surface are not significant, so another type of analysis must be done to measure the thicknesses because it may be that instead of thickening the thickness of the layer, only the spaces available on the surface have been filled. and there are not as many sites of interaction due to the roughness of the surface [49]. PDA increases the hydrophilicity of the surface by exposing more -OH groups on the surface, forcing the RBCs to adhere to the surface, forming hydrophilic interactions, which makes it easier for red blood cells to adhere less strongly.

Figure 6a shows a graphical distribution of adhered RBC on the samples. Figure $6 \mathrm{~d}$ which corresponds to the functionalized catheter exposed to red blood cells, it can be clearly seen that there is a smaller number of clusters of red blood cells on the surface compared to the catheter only corresponding to Figure $6 \mathrm{~b}$. 


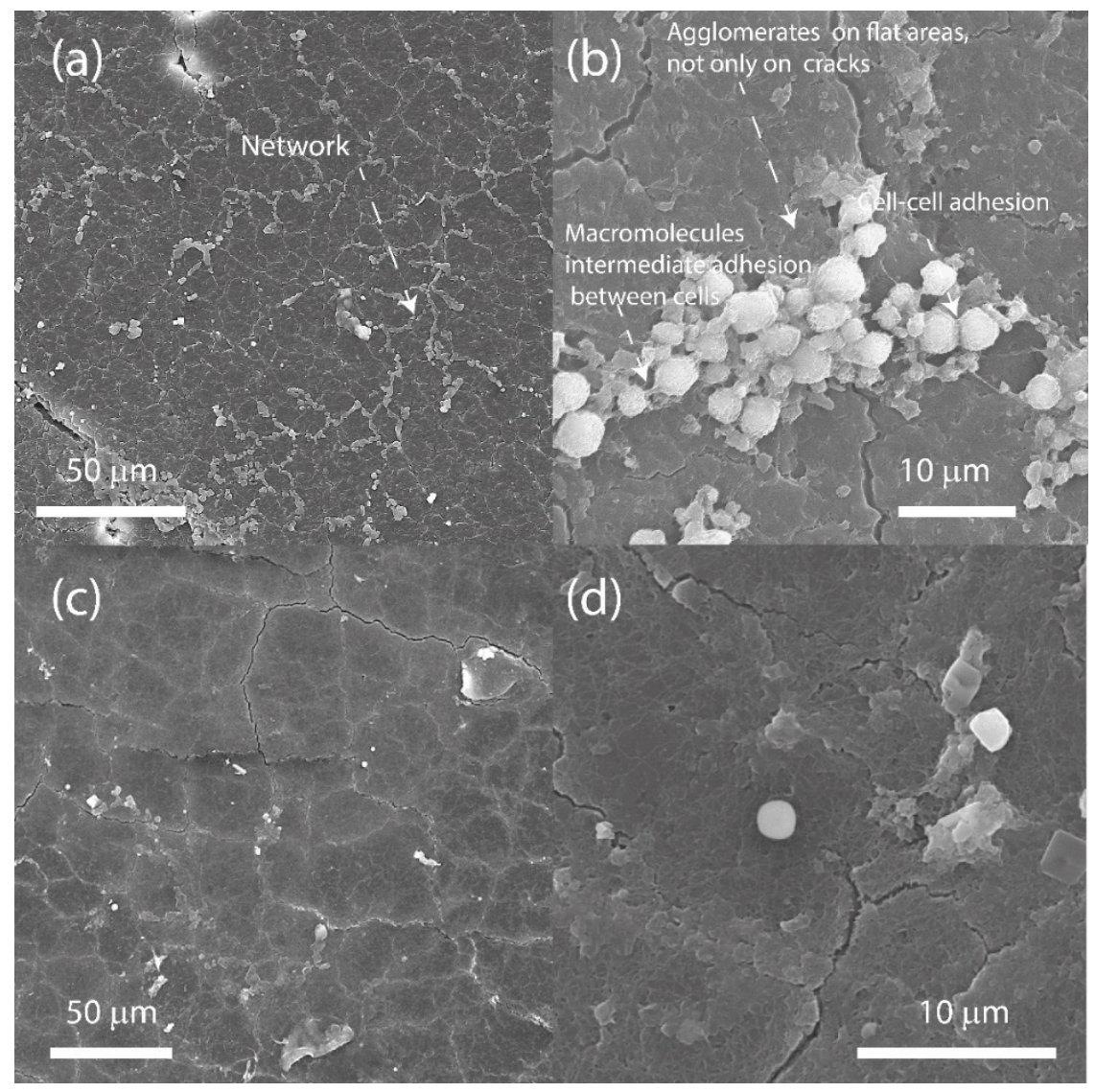

Figure 6. Comparison of the images corresponding to the catheter surface with adhered RBC before and after functionalization with PDA-Ext: (a) pristine catheter at $300 \times,($ b) pristine catheter at $2000 \times$, (c) $300 \times$ functionalized catheter, and (d) $2000 \times$ functionalized catheter.

The adhesion of the RBCs occurs in the flattest parts as we can see in the SEM microscopies, while the cracks are exposed and do not promote the adhesion of the RBCs. Additionally, as occurs in circulation, platelets and other blood components adhere to collagen, fibronectin, laminin, vitronectin, and thrombospondin in the subendothelium to form conglomerates of RBC on the surface. In addition, RBC adhesion can occur between them, or it can be mediated by macromolecules or there is intervention of the extracellular matrix as can be seen in Figure 6. The morphology of the red blood cells in Figure 6 is described as discocyte, which corresponds to the normal form of RBCs. Additionally, spherocytes can be seen that can be caused by a hypotonic environment that could be caused by the treatment that was given to the sample [50].

We prepared a SYLGARD ${ }^{\mathrm{TM}} 184$ silicone elastomer model in an attempt to mimic a flat catheter surface for a better measurement by AFM and to avoid the influence of roughness. Contact angle measurements were carried out to verify that the model and the catheter had similar wettability. They were also verified to have similar functional groups by FTIR. The model substrate was functionalized under the same conditions as the catheter.

Figure 7a,b shows the morphology of the RBC adhered to the control, and functionalized substrate, respectively. Figure 7c,d shows the line cross-section shown in Figure 7a,b, respectively. Figure $7 \mathrm{e}, \mathrm{f}$ shows the area where the indentation was done and a representative force vs indentation curve obtained for the cells adhered to the control surface. The RBC attached to the control surface shows a flat discoid morphology and a diameter and height average of of $6.8 \pm 1 \mu \mathrm{m}$ and $1.5 \pm 5 \mu \mathrm{m}$, respectively. The RBC adhered to the functionalized surface shows a rounder morphology than the adhered to the control surface and a diameter and height average of $7.6 \pm 0.8 \mu \mathrm{m}$ and $1.7 \pm 5 \mu \mathrm{m}$, respectively. In Figure $7 \mathrm{~g}, \mathrm{~h}$, it is possible to notice the frequency distribution of the EC values in the RBCs found on the 
pristine surface and functionalized substrate model substrate, respectively. It is possible to observe a decrease in the EC values of the RBCs presented on the functionalized model surface compared to the RBCs presented on the model surface without treatment.
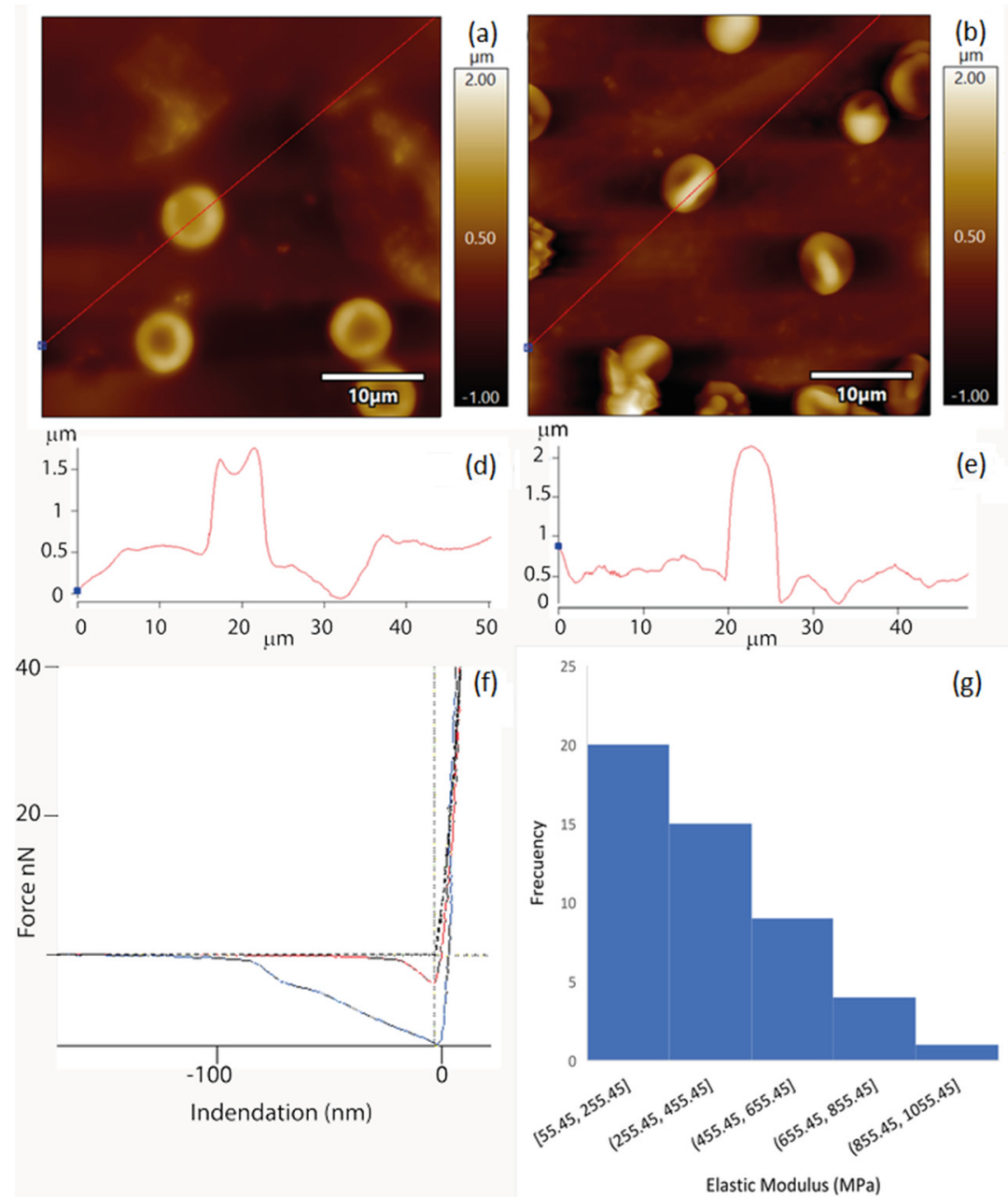

(b)

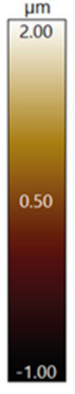

(e)

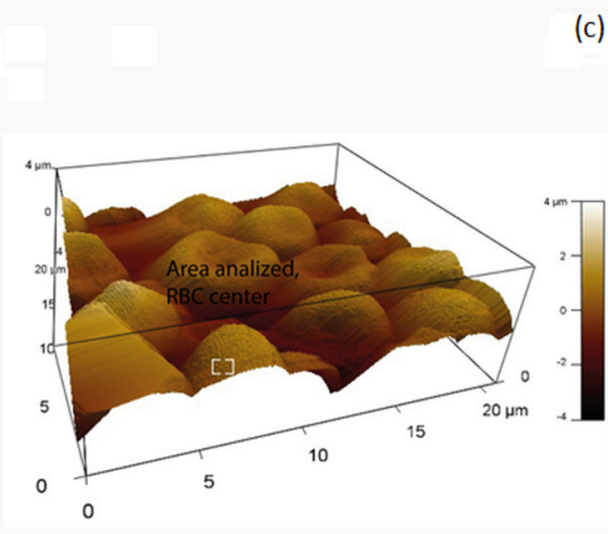

(c)

c)

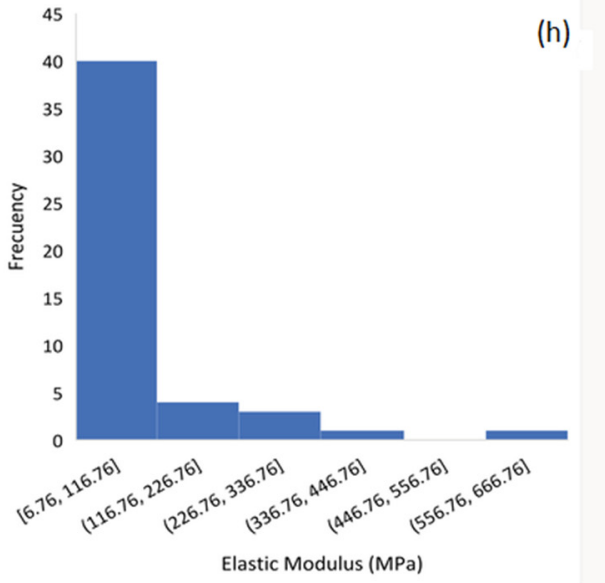

Figure 7. AFM height image of RBC adhered to (a) control and (b) functionalized surface. (c) Threedimensional AFM image of the RBC cells on the model substrate. (d) and (e) Line cross-section of the RBC cell highlighted in a and $b$, respectively. (f) Representative force vs indentation curve of a point on the central area of the RBC adhered to control surface; $(\mathbf{g}, \mathbf{h})$ distribution of values according to the frequency of the RBC elastic modulus of the cells adhered to the control and functionalized surface, respectively.

\section{Discussion}

Previous studies identified and quantified anthocyanins, flavonoids, and PACs in blueberry crops and have suggested that ethanolic extractions are highly capable of solubilizing tannins covalently attached to the fruit's cell wall [51,52], as also demonstrated in this study. According to the FTIR spectra, peaks corresponding to the characteristic functional groups of phenolic compounds such as condensed tannins were observed in the extract spectra.

For stabilizing the PACs on the catheter surface, phenol oxidizing laccase was added to the reaction media to improve the formation of covalent bonds. For this purpose, a calorimetric study was carried out to determine whether the enzyme could oxidize polyphenolic compounds in the extract. The results shown in Figure $2 \mathrm{~b}$ suggest that the enzyme could oxidize the phenolic compounds of the extract that could further react with the PDA coating. The presence of new functional groups on the surface is corroborated by measuring the increase in roughness and decrease in water contact angle in comparison with the control 
surface. The aromatic $-\mathrm{OH}$ and aromatic-O groups could improve the affinity of the surface with the water and change its wettability [47]. Polydopamine (PDA) is produced from the oxidative polymerization or self-assembly of catecholamines in alkaline aqueous solutions; it is characterized by a strong adhesion on varied substrates through covalent bonds and intermolecular interactions. This property has been used as an interfacial adhesion medium for biomedical applications. [53,54]. PDA treatment has been applied to PDMS substrates, as well as PDMS-based closed microfluidic systems that are used in in vitro studies of cell physiology. [53] Park et al. performed a chemical modification on the surface of a polydimethylsiloxane (PDMS) substrate using polydopamine (PDA), which was spontaneously deposited through an immersion process coating to form a thin, biocompatible film that favored adhesion of the extracellular matrix (ECM) hydrogel scaffolds. Under dynamic conditions, the hydrogel matrix in the PDA-treated substrate remained intact without gel shedding [54]. Chuah et al. modified the surface of a PDMS substrate with PDA to improve biocompatibility for the culture of bone marrow stromal cells (BMSC), determining that the modification of the PDMS surface chemistry due to PDA could have predominant effects in BMSC culture regardless of surface hydrophobicity changes. [55] Similarly, Dabaghi et al. compared a static and dynamic PDA coating for PDMS microfluidic devices. These PDA coatings were used to bind collagen within devices and enhance cell adhesion of human bronchial epithelial cells. [55] PDA's adhesion strength is provided by these catechol groups that form hydrogen bonds with the silicone surface [30]. Generally, PDA films are heterogeneous and encompass oligomeric segments and supramolecular aggregates assembled by van der Waals interactions and hydrogen bonds [31]. The deposition and adhesion behavior of the polydopamine on different surfaces is not yet well understood. Zhang et al. reported that the wettability has a significant influence on the adhesion and that hydrophobic surface enhances the PDA adhesion [56]

When it comes to interfacial applications between components and tissues for the medical industry, the interfaces are often weak, which can lead to delamination during long-term implantation and biological sequelae. Within efforts to improve this problem, Xue et al. designed and manufactured a hydrogel bio adhesive that is capable of instant and robust adhesion and enables release triggered by on-demand stimuli. This adhesion of the hydrogel arises from the fact that it is given by biomimetic interfacial water drainage, synergistic hydrogen bonds and chemical crosslinking. [57] Similarly, Liu et al. developed a strategy for fatigue-resistant adhesion of hydrogels on various engineering materials by joining ordered nanostructures in hydrogels from engineering materials. [58] We believe that our coating can also serve as a possible base for low tack hydrogels that are used in removable hydrogel adhesives for bioelectronics.

After the PDA layer formation, the extract was in contact with the surface substrate for $24 \mathrm{~h}$ for PAC immobilization. There is an increase in the hydrophilicity of the surface with respect to that of the substrate functionalized only with PDA from $63^{\circ} \pm 3^{\circ}$ to $20^{\circ} \pm 3^{\circ}$. When the functionalized substrate was rinsed for $24 \mathrm{~h}$ with PBS and culture media, the functionalization partially remained due to the lower contact angle and ATR-FTIR peak intensity changes. The higher hydrophilicity in the substrate rinsed with cell culture media-enriched BSA may be due to the protein adsorption on the surface.

Figure 6 shows the RBC agglomerates formed on the pristine and functionalized catheter. Figure $6 c$,d shows fewer clusters of RBC are found on the functionalized surface than in the pristine catheter. The adhesion of the RBCs on the catheter surface occurred on the flat areas and within the cracks. However, few clusters of RBC were found on the functionalized catheter. The organic material surrounding the cells suggests that platelets and other blood components such as collagen, fibronectin, laminin, vitronectin, and thrombospondin adhered to the surface and form part of the clusters as it happens during blood circulation Figure $6 \mathrm{~b}$ shows cell-cell binding and cells bound by an intermediary macromolecule or intervention of the extracellular matrix. The morphology of the red blood cells in Figure 6 is described as discocyte, which corresponds to the normal form of RBCs. Additionally, spherocytes can be seen that can be caused by a hypotonic environment that 
could be caused during the cross-linking of the cells or even due to the friction during the blood pipetting [50].

Adhesion of thrombocytes to the surfaces of materials and coagulation cascade are mediated by surface-bound proteins, including Von Willebrand factor (vWB), fibrinogen, vitronectin, and albumin. These proteins present in the extracellular medium (ECM) are immediately adsorbed on the surface of materials to form a layer that promotes cell adhesion [59]. Lower adsorption of blood proteins may represent the higher capacity of the functionalized catheter to inhibit RBC and thrombocytes' adhesion to the surface [60]. Lower albumin adsorption means that adhesive proteins such as fibrinogen could interact more directly with the substrate and be de-natured, decreasing the probability of fibrin formation [61].

To analyze the adhesion behavior of RBC on the catheter surface, we followed the experiment proposed by Leslie $\mathrm{D}$ et al. [35]. We added a 3\% RBC solution on different samples of the catheter for one hour and then rinsed. When the catheter is functionalized with PDA-Ext, the amount of RBC adhered to the surface decreases when compared to the catheter with extract alone. This result suggests that the coating is effective against blood agglutination on the catheter surface.

Dang et al. showed that the platelet adhesion was dependent on the PDA layer thickness due to the formation of aggregates that increase the surface contact area and, consequently, protein adsorption. However, further immobilization of these layer with phosphorylcholine copolymer decreased platelet adhesion by $99 \%$. To determine whether the PDA film influences the coating performance, we produced PDA films with two different roughness, and then these samples were in contact with the extract for $24 \mathrm{~h}$, as described previously. The results suggest that PDA thickness does have an influence RBC adhesion. Our results show that thicker PDA layers were formed on the catheter surface when the contact time with the dopamine solution increased. Furthermore, thicker PDA layers decreased the RBC adhesion. Dang et al. 2015 reported an opposite result for adhesion on thicker PDA layers for platelets [49]. We hypothesize that the RBC adhesion reduction with PDA is due to higher interaction with the cell membrane inhibiting the interaction between cells and other blood cell components as suggested by the antigenic shielded effect of the PDA on RBC [62]. A layer roughness increased indicates a thicker layer. Thicker layers could increase the density of the $\mathrm{OH}$ groups on the surface, enhancing the interfacial adhesion of the proteins and cells based on hydrophilic interactions, making it easier for red blood cells to adhere less strongly than when they profit from hydrophobic interactions. The film maintained similar morphology, and no other nanostructures that increased the surface area were detected. Further studies are necessary to determine the reason for PDA film thickness on the RBC adhesion.

This research has focused on evaluating changes in the membrane of red blood cells caused by polyphenols and how these changes can modify the mechanical properties of the cell membrane. The polyphenolic structure of flavonoids gives them the ability to interact with biological membranes, eliminating free radicals; thus, they also act directly as transition metal chelators on the membranes. Such interactions could result in an alteration in the arrangement of the lipids of the membrane at different depths of the lipid bilayer. This interaction has been shown to be concentration dependent, increasing the fluidity of the membrane near the surface [63]. This result is also reaffirmed in the research proposed by Visser, J et al. in which it was shown that the protective antioxidant properties of PACs increased the elasticity of the membrane [63]. It was experimentally verified that blueberry extract in solution can agglomerate $R B C$, but only at very high concentrations $(\geq 160 \mathrm{mg} / \mathrm{mL})$. Additionally, at low concentrations $(\leq 80 \mathrm{mg} / \mathrm{mL})$, this effect was not observed.

The fluidity of the membrane has been shown to play a decisive role in the efficiency of the cell's binding to the ligand; this fluidity depends on the freedom of mobility of the membrane components [64]. Several studies have suggested a direct proportional correlation between red blood cell deformability and membrane fluidity [65]. In this sense, 
greater deformability of the membrane is correlated with a lower elastic modulus (EC) and greater fluidity in the membrane. Classical studies have revealed that surfactants fluidized the cell membrane, weakening cell adhesion. Recently, polyphenols such as tannic acid (TA) have been used as surfactants for different purposes due to environmental concerns and the high availability of polyphenols in nature $[66,67]$. Research proposed by Takahisa $\mathrm{M}$ et al. used natural polyphenols as surfactants to modulate the membrane fluidity of stem cells and reduce cell adhesion without toxic effects relative to their early differentiated progeny [68].

Morphological AFM analysis of the cells adhered to the samples showed that the few cells adhered to the PDA-Ext were larger in height and width than the cells adhered to the native surface, suggesting that the larger cells adhered to the catheter by increasing the adhesion points with the surface [51]. Nanoindentation has become a useful tool to determine properties such as the elastic modulus (EC) of biological samples. Cantilevers serve as nano-introducers that allow for the testing of small, inhomogeneous samples such as cells. Various models are used to calculate EC, but most of them are based on the Hertz model [69]. For our indentation experiment, we performed measurements to obtain force-distance curves in the central region of the RBC. This information is provided by mechanical mapping using AFM, in which curves are obtained in each pixel of the image of the central cell region. The quantification of the elasticity of the cells was measured from a central region. Central and peripherals regions of the cell show elasticity differences of up to four orders of magnitude, from tens of Pa to hundreds of $\mathrm{kPa}$ [70], and the area should be set before the experiment. Cell adhesion determines cell elasticity; consequently, the structures formed by cells differ and the actin cytoskeleton reorganizes in a patterndependent manner. Non-adherent cell areas are generally softer than adherent cells [70]. It is possible to observe a decrease in the EC values of the RBCs presented on the treated model's surface compared to the RBCs presented on the model's surface without treatment.

Other studies reported that red blood cells loosely attached to the substrate show a decrease in EC given the presumption of the Hertz model [69]. The lower EC could be associated with the membrane state [71]. The cell adhesion determines the cell elasticity that is correlated with the reorganization of the actin cytoskeleton. Non-adherent cell areas are generally softer than adherent cells [72]. Our results suggest that the blueberry extract coating can repel the adhesion of red blood cells to the surface due to changes in the fluidity of the RBC membrane, which influences adhesion to the substrate.

\section{Conclusions}

The ethanolic extract of blueberry contained polyphenols and PACs. We consider that the use of ethanol is a viable option for the extraction of PACs, as described by previous research. We achieved a stable functionalization of the silicone catheter with the PDA + Ext on the originally hydrophobic surface. The RMS on the surface of the functionalized catheter was greater than that of the original. This finding, paired with an increase in surface wettability and the presence of hydroxyl groups, demonstrates the presence of the PDA + Ext coating on the surface. Furthermore, functionalization prevails after rinsing with bacteria and cell culture media. The PDA + Ext coating on the catheter surface was able to reduce blood protein adhesion compared to the original catheter surface; the percentage of reduction in albumin and plasma protein adhesion to the surface was approximately $15.2 \%$ and $7.65 \%$, respectively. We suggest that the decrease in the adhesion of blood proteins to the surface could have a decreasing effect on the adhesion and aggregation of red blood cells on the surface. In this regard, we observed a reduction of approximately $60 \%$ in the adhesion of RBC when the catheter surface had the PDA + PAC coating, compared with the adhesion of RBC to the original surface; furthermore, the SEM images showed an RBC agglutination effect on the surface of the pristine catheter, which was not observed on the functionalized surface. We also consider that the molecular size of the PACs may cause a steric hindrance effect that could contribute to the RBC repellent effect of the coating. AFM indentation experiments showed a distribution of Young's modulus measurements of 
red blood cells adhered to the original catheter, in which most of the values were between 55.45 and $655.45 \mathrm{MPa}$, while the few RBCs found adhered to the PDA-PAC-coated catheter showed that most of the measurements shifted between 6.76 and 116.76 MPA. This lower Young's modulus indicates that the RBCs were not well adhered to the coated surface. Since a decrease in the fluidity of the RBC membrane is directly related to a decrease in its stiffness, and a low stiffness is correlated with a lower Young's modulus, we suggest that PACs are capable of modifying adhesion to the functionalized surface, first modifying the RBC membrane in contact with the hydroxyl groups and thus changing the biomechanical properties of the cell toward the substrate.

Our findings on changes in the adhesion of RBC to a silicone surface due to PDA + Ext coating could be important in the development of surfaces that inhibit thrombus formation in silicone medical devices that come into contact with blood. For further experiments, it might be useful to expose the substrates to autoclaving processes, emulating the sterilization that medical devices would undergo at the industrial production level, and thus evaluate the stability of the coating after exposure to higher temperatures.

Author Contributions: V.O.-F. and S.G.-S. carried out the main experimental protocols; interpretation and data analysis. J.C. did the protein adsorption test and proanthocyanidins and polyphenols quantification; K.R. helped to analyze the data; Y.C.-U. did the SEM and AFM analysis; Y.C.-U. and J.V.B. did the critical review of the manuscript. All authors have read and agreed to the published version of the manuscript.

Funding: This research received no external funding.

Institutional Review Board Statement: Fanny Chan Solano from UCIMED Costa Rica for the ethical revision of the project (UCIMED Costa Rica, CEC-0488-2021).

Informed Consent Statement: Not applicable.

Data Availability Statement: Data sharing is not applicable to this article.

Acknowledgments: To Sergio Paniagua from LANOTEC for the help with the materials to produce the PDMS model substrate and Melissa Castro for the support with some biological experiments. To Jorge Cubero for the advice and support during V.O.-F. and S.G.-S. development of the master studies.

Conflicts of Interest: The authors declare no conflict of interest.

\section{References}

1. Medical Grade Silicone Market. Available online: https://www.marketsandmarkets.com/Market-Reports/medical-gradesilicone-market-36328567.html\#/ (accessed on 9 December 2021).

2. Lim, K.K. Development of anti-fouling materials for blood-contacting devices. Oaktrust. Library Tamu. Edu. 2021. Available online: https:/ / oaktrust.library.tamu.edu/handle/1969.1/194466 (accessed on 8 December 2021).

3. Ngo, B.K.D.; Barry, M.E.; Lim, K.K.; Johnson, J.C.; Luna, D.J.; Pandian, N.K.; Jain, A.; Grunlan, M.A. Thromboresistance of silicones modified with PEO-silane amphiphiles. ACS Biomater. Sci. Eng. 2020, 6, 2029-2037. [CrossRef] [PubMed]

4. Pfeifer, S.; Butts, S.; Dumesic, D.; Fossum, G.; Gracia, C.; La Barbera, A.; Mersereau, J.; Odem, R.; Penzias, A.; Pisarska, M.; et al. Combined hormonal contraception and the risk of venous thromboembolism: A guideline. Fertil. Steril. 2016, 107, 43-51. [CrossRef] [PubMed]

5. Di Nisio, M.; Carrier, M.; Lyman, G.H.; Khorana, A.; Malignancy, T.S.O.H.A. Prevention of venous thromboembolism in hospitalized medical cancer patients: Guidance from the SSC of the ISTH. J. Thromb. Haemost. 2014, 12, 1746-1749. [CrossRef]

6. Jaffer, I.H.; Fredenburgh, J.C.; Hirsh, J.; Weitz, J.I. Medical device-induced thrombosis: What causes it and how can we prevent it? J. Thromb. Haemost. 2015, 13, S72-S81. [CrossRef]

7. Lavery, K.S.; Rhodes, C.; Mcgraw, A.; Eppihimer, M.J. Anti-thrombotic technologies for medical devices. Adv. Drug Deliv. Rev. 2016, 112, 2-11. [CrossRef]

8. Hong, J.K.; Gao, L.; Singh, J.; Goh, T.; Ruhoff, A.M.; Neto, C.; Waterhouse, A. Evaluating medical device and material thrombosis under flow: Current and emerging technologies. Biomater. Sci. 2020, 8, 5824-5845. [CrossRef]

9. Weber, M.; Steinle, H.; Golombek, S.; Hann, L.; Schlensak, C.; Wendel, H.; Avci-Adali, M. Blood-contacting bio-materials: In vitro evaluation of the hemocompatibility. Front. Bioeng. Biotechnol. 2018, 6, 99. [CrossRef]

10. Puri, R.N.; Colman, R.W.; Liberman, M.A. ADP-induced platelet activation. Crit. Rev. Biochem. Mol. Biol. 1997, 32, 437-502. [CrossRef] 
11. Sosa, V.; Gladys, A. Efectividad del Sellado del Catéter Venoso Central de Alto Flujo Con Antimicrobianos y Anticoagulantes vs el Sellado con Anticoagulante en la Prevención de Infecciones. Repositorio. Uwiener. Edu. Pe. 2021. Available online: http:/ / re-positorio.uwiener.edu.pe/handle/123456789/4618 (accessed on 9 December 2021).

12. Cardoso, R.; D'Avila, A. Anticoagulantes orais diretos ininterruptos em ablação por cateter de fibrilação atrial: Pronto para a prática clínica. Arq. Bras. Cardiol. 2020, 114, 443-445. [CrossRef] [PubMed]

13. Trejo, C. Anticoagulantes: Farmacología, mecanismos de acción y usos clínicos. Cuad. De Cirugía 2004, 18, 83-90. [CrossRef]

14. Guía Sobre los Anticoagulantes Orales de Acción Directa (Sociedad Española de Hematología y Hemoterapia/Sociedad Española de Trombosis y Hemostasia). Available online: https://www.seth.es/images/files/guia-nuevos-anticoagulantes-orales.pdf (accessed on 9 December 2021).

15. Bassas, P.; Bartralot, R.; García-Patos, V. Anticoagulación y antiagregación en dermatología. Actas Dermo-Sifiliográficas 2009, 100, 7-16. [CrossRef]

16. Ham, H.O.; Haller, C.A.; Su, G.; Dai, E.; Patel, M.S.; Liu, D.R.; Liu, J.; Chaikof, E.L. A rechargeable anti-thrombotic coating for blood-contacting devices. Biomaterials 2021, 276, 121011. [CrossRef]

17. Li, C.; Du, H.; Yang, A.; Jiang, S.; Li, Z.; Li, D.; Brash, J.L.; Chen, H. Thrombosis-responsive thrombolytic coating based on thrombin-degradable tissue plasminogen activator (t-PA) nanocapsules. Adv. Funct. Mater. 2017, 27, 1703934. [CrossRef]

18. Li, L.; Yang, L.; Liao, Y.; Yu, H.; Liang, Z.; Zhang, B.; Lan, X.; Luo, R.; Wang, Y. Superhydrophilic versus normal polydopamine coating: A superior and robust platform for synergistic antibacterial and antithrombotic properties. Chem. Eng. J. 2020, 402, 126196. [CrossRef]

19. Wang, L.; Li, H.; Chen, S.; Nie, C.; Cheng, C.; Zhao, C. Interfacial self-assembly of heparin-mimetic multilayer on membrane substrate as effective antithrombotic, endothelialization, and antibacterial coating. ACS Biomater. Sci. Eng. 2015, 1, 1183-1193. [CrossRef]

20. Yamamoto, J.; Naemura, A.; Ura, M.; Ijiri, Y.; Yamashita, T.; Kurioka, A.; Koyama, A. Testing various fruits for anti-thrombotic effect: I. Mulberries. Platelets 2006, 17, 555-564. [CrossRef]

21. Nignpense, B.E.; Chinkwo, K.A.; Blanchard, C.L.; Santhakumar, A.B. Polyphenols: Modulators of platelet function and platelet microparticle generation? Int. J. Mol. Sci. 2019, 21, 146. [CrossRef]

22. Ostertag, L.M.; O'Kennedy, N.; Kroon, P.A.; Duthie, G.G.; de Roos, B. Impact of dietary polyphenols on human platelet function-A critical review of controlled dietary intervention studies. Mol. Nutr. Food Res. 2010, 54, 60-81. [CrossRef]

23. Zhang, Y.; Shi, H.; Wang, W.; Ke, Z.; Xu, P.; Zhong, Z.; Li, X.; Wang, S. Antithrombotic effect of grape seed proanthocyanidins extract in a rat model of deep vein thrombosis. J. Vasc. Surg. 2011, 53, 743-753. [CrossRef] [PubMed]

24. Latos-Brozio, M.; Masek, A. Effect of impregnation of biodegradable polyesters with polyphenols from cistus linnaeus and juglans regia linnaeus walnut green husk. Polymers 2019, 11, 669. [CrossRef] [PubMed]

25. Yang, L.; Han, L.; Jia, L. A novel platelet-repellent polyphenolic surface and its micropattern for platelet adhesion detection. ACS Appl. Mater. Interfaces 2016, 8, 26570-26577. [CrossRef]

26. Ong, G.; Kasi, R.; Subramaniam, R. A review on plant extracts as natural additives in coating applications. Prog. Org. Coat. 2020, 151, 106091. [CrossRef]

27. Yassin, M.A.; Elkhooly, T.; Elsherbiny, S.M.; Reicha, F.M.; Shokeir, A.A. Facile coating of urinary catheter with bio-inspired antibacterial coating. Heliyon 2019, 5, e02986. [CrossRef] [PubMed]

28. Liebscher, J.; Mrówczyński, R.; Scheidt, H.A.; Filip, C.; Hădade, N.D.; Turcu, R.; Bende, A.; Beck, S. Structure of polydopamine: A never-ending story? Langmuir 2013, 29, 10539-10548. [CrossRef]

29. Almeida, L.; Correia, R.; Squillaci, G.; Morana, A.; La Cara, F.; Correia, J.; Viana, A. Electrochemical deposition of bio-inspired laccase-polydopamine films for phenolic sensors. Electrochim. Acta 2019, 319, 462-471. [CrossRef]

30. Liu, Y.; Ai, K.; Lu, L. Polydopamine and its derivative materials: Synthesis and promising applications in energy, environmental, and biomedical fields. Chem. Rev. 2014, 114, 5057-5115. [CrossRef]

31. Singleton, V.L.; Orthofer, R.; Lamuela-Raventós, R.M. Analysis of total phenols and other oxidation substrates and antioxidants by means of folin-ciocalteu reagent. Methods Enzymol. 1999, 299, 152-178.

32. Liu, L.; Xie, B.; Cao, S.; Yang, E.; Xu, X.; Guo, S. A-type procyanidins from Litchi chinensis pericarp with antioxidant activity. Food Chem. 2007, 105, 1446-1451. [CrossRef]

33. Lim, J.I.; Kim, S.I.; Kim, S.H. Lotus-leaf-like structured heparin-conjugated poly(L-lactide-co- $\varepsilon$-caprolactone) as a blood compatible material. Colloids Surf. B Biointerfaces 2013, 103, 463-467. [CrossRef] [PubMed]

34. Neffe, A.T.; von Ruesten-Lange, M.; Braune, S.; Lützow, K.; Roch, T.; Richau, K.; Krüger, A.; Becherer, T.; Thünemann, A.F.; Jung, F.; et al. Multivalent grafting of hyperbranched oligo- and polyglycerols shielding rough membranes to mediate hemocompatibility. J. Mater. Chem. B 2014, 2, 3626-3635. [CrossRef] [PubMed]

35. Leslie, D.C.; Waterhouse, A.; Hicks-Berthet, J.; Valentin, T.M.; Watters, A.L.; Jain, A.; Kim, P.; Hatton, B.D.; Nedder, A.; Donovan, K.; et al. A bioinspired omniphobic surface coating on medical devices prevents thrombosis and biofouling. Nat. Biotechnol. 2014, 32, 1134-1140. [CrossRef] [PubMed]

36. Jensen, J.S.; Egebo, M.; Meyer, A.S. Identification of spectral regions for the quantification of red wine tannins with fourier transform mid-infrared spectroscopy. J. Agric. Food Chem. 2008, 56, 3493-3499. [CrossRef] [PubMed]

37. Pantoja-Castro, M.A.; González-Rodríguez, H. Study by infrared spectroscopy and thermogravimetric analysis of tannins and tannic acid. Rev. Latinoam. Química 2011, 39, 107-112. 
38. Wang, Y.; Wang, G.; Moitessier, N.; Mittermaier, A.K. Enzyme kinetics by isothermal titration calorimetry: Allostery, inhibition, and dynamics. Front. Mol. Biosci. 2020, 7, 583826. [CrossRef]

39. Pino-Ramos, V.H.; Alvarez-Lorenzo, C.; Concheiro, A.; Bucio, E. One-step grafting of temperature-and pH-sensitive (Nvinylcaprolactam-co-4-vinylpyridine) onto silicone rubber for drug delivery. Des. Monomers Polym. 2016, 20, 33-41. [CrossRef]

40. I Salih, S.; Oleiwi, J.; Ali, H.M. Study the mechanical properties of polymeric blends (SR/PMMA) using for maxillofacial prosthesis application. IOP Conf. Ser. Mater. Sci. Eng. 2018, 454, 012086. [CrossRef]

41. Lagutschenkov, A.; Langer, J.; Berden, G.; Oomens, J.; Dopfer, O. Infrared spectra of protonated neurotransmitters: Dopamine Phys. Chem. Chem. Phys. 2010, 13, 2815-2823. [CrossRef]

42. Yadav, T.; Mukherjee, V. Interpretation of IR and Raman spectra of dopamine neurotransmitter and effect of hydrogen bond in HCl. J. Mol. Struct. 2018, 1160, 256-270. [CrossRef]

43. Wang, J.; Zhou, S.; Jin, H.; Zhao, G.; Liu, Y. Interfacial modification of basalt fiber filling composites with graphene oxide and polydopamine for enhanced mechanical and tribological properties. RSC Adv. 2018, 8, 12222-12231. [CrossRef]

44. Nycz, M.; Ewa, P.; Katarzyna, A.; Bartosz, K.; Elzbieta, K.C. Surface Analysis of Long-Term Hemodialysis Catheters Made of Carbothane (Poly(carbonate)urethane) before and after Implantation in the Patients' Bodies. Acta Bioeng. Biomech. 2021, 20. Available online: https:/ / pubmed.ncbi.nlm.nih.gov/30220724/ (accessed on 9 December 2021).

45. Jegatheeswaran, A.; Parmar, N.; Walton, J.M.; Yip, C.; Chan, A.K.C. Quantitative analysis of catheter roughness induced by cutting and manipulation: A potential prothrombotic risk. Blood Coagul. Fibrinolysis 2007, 18, 531-536. [CrossRef] [PubMed]

46. Zheng, W.; Sun, C.; Bai, B. Molecular dynamics study on the effect of surface hydroxyl groups on three-phase wettability in oil-water-graphite systems. Polymers 2017, 9, 370. [CrossRef] [PubMed]

47. Zhang, A.; Li, J.; Zhang, S.; Mu, Y.; Zhang, W.; Li, J. Characterization and acid-catalysed depolymerization of condensed tannins derived from larch bark. RSC Adv. 2017, 7, 35135-35146. [CrossRef]

48. Sanjay, R.; Sabyasachi, G.; Tushar, K.D.; Maya, S.; Madhuparna, B.; Suryasarathi, B.; Amit, K.D.; Narayan, C.D. Gradient crystallinity and its influence on the poly (vinylidene fluoride)/poly (methyl methacrylate) membrane-derived by immersion precipitation method. J. Appl. Polym. Sci. 2020, 137, 48677.

49. Dang, Y.; Xing, C.-M.; Quan, M.; Wang, Y.-B.; Zhang, S.-P.; Shi, S.-Q.; Gong, Y.-K. Substrate independent coating formation and anti-biofouling performance improvement of mussel inspired polydopamine. J. Mater. Chem. B 2015, 3, 4181-4190. [CrossRef]

50. Daniel Amadeus Dominic Flormann. Physical Charaterization of Red Blood Cell Aggregation. Ph.D. Thesis, Universität des Saarlandes, Saarbrücken, Germany, August 2017.

51. Wang, Y.; Fong, S.K.; Singh, A.P.; Vorsa, N.; Johnson-Cicalese, J. Variation of anthocyanins, proanthocyanidins, flavonols, and organic acids in cultivated and wild diploid blueberry species. HortScience 2019, 54, 576-585. [CrossRef]

52. Chuah, Y.J.; Koh, Y.T.; Lim, K.; Menon, N.V.; Wu, Y.; Kang, Y. Simple surface engineering of polydimethylsiloxane with polydopamine for stabilized mesenchymal stem cell adhesion and multipotency. Sci. Rep. 2015, 5, 18162. [CrossRef]

53. Park, S.E.; Georgescu, A.; Oh, J.M.; Kwon, K.W.; Huh, D. Polydopamine-based interfacial engineering of extracellular matrix hydrogels for the construction and long-term maintenance of living three-dimensional tissues. ACS Appl. Mater. Interfaces 2019, 11, 23919-23925. [CrossRef]

54. Dabaghi, M.; Shahriari, S.; Saraei, N.; Da, K.; Chandiramohan, A.; Selvaganapathy, P.; Hirota, J. Surface modification of PDMSbased microfluidic devices with collagen using polydopamine as a spacer to enhance primary human bronchial epithelial cell adhesion. Micromachines 2021, 12, 132. [CrossRef] [PubMed]

55. Zhang, C.; Gong, L.; Xiang, L.; Du, Y.; Hu, W.; Zeng, H.; Xu, Z.-K. Deposition and adhesion of polydopamine on the surfaces of varying wettability. ACS Appl. Mater. Interfaces 2017, 9, 30943-30950. [CrossRef] [PubMed]

56. Xue, Y.; Zhang, J.; Chen, X.; Zhang, J.; Chen, G.; Zhang, K.; Lin, J.; Guo, C.; Liu, J. Trigger-detachable hydrogel adhesives for bioelectronic interfaces. Adv. Funct. Mater. 2021, 31, 2106446. [CrossRef]

57. Liu, J.; Lin, S.; Liu, X.; Qin, Z.; Yang, Y.; Zang, J.; Zhao, X. Fatigue-resistant adhesion of hydrogels. Nat. Commun. 2020, 11, 1-9. [CrossRef] [PubMed]

58. Busse, V.N. Proantocianidinas de Uvas Y Vinos de las Variedades Monastrell, Cabernet Sauvignon Y Syrah. Ph.D. Thesis, Universidad de Murcia, Departamento de Tecnología de Alimentos, Nutrición y Bromatología, 2013.

59. Yun, S.-H.; Sim, E.-H.; Goh, R.-Y.; Park, J.-I.; Han, J.-Y. Platelet activation: The mechanisms and potential biomarkers. BioMed Res. Int. 2016, 2016, 1-5. [CrossRef] [PubMed]

60. Anselme, K.; Ploux, L.; Ponche, A. Cell/material interfaces: Influence of surface chemistry and surface topography on cell adhesion. J. Adhes. Sci. Technol. 2010, 24, 831-852. [CrossRef]

61. Wang, B.; Wang, G.; Zhao, B.; Chen, J.; Zhang, X.; Tang, R. Antigenically shielded universal red blood cells by polydopamine-based cell surface engineering. Chem. Sci. 2014, 5, 3463-3468. [CrossRef]

62. Weckman, N.E.; Olsson, A.L.J.; Tufenkji, N. Evaluating the binding of selected biomolecules to cranberry derived proanthocyanidins using the quartz crystal microbalance. Biomacromolecules 2014, 15, 1375-1381. [CrossRef]

63. Visser, J.; Van Staden, P.J.; Soma, P.; Buys, A.V.; Pretorius, E. The stabilizing effect of an oligomeric proanthocyanidin on red blood cell membrane structure of poorly controlled Type II diabetes. Nutr. Diabetes 2017, 7, e275. [CrossRef]

64. Hollán, S. Membrane fluidity of blood cells. Haematologia 1996, 27, 109-127. 
65. Sonmez, M.; Ince, H.Y.; Yalcin, O.; Ajdzanovic, V.; Spasojevic, I.; Meiselman, H.J.; Baskurt, O.K. The effect of alcohols on red blood cell mechanical properties and membrane fluidity depends on their molecular size. PLoS ONE 2013, 8, e76579. [CrossRef] [PubMed]

66. Payra, D.; Yamauchi, Y.; Samitsu, S.; Naito, M. Natural polyphenol surfactants: Solvent-mediated spherical nanocontainers and their stimuli-responsive release of molecular payloads. Chem. Mater. 2018, 30, 8025-8033. [CrossRef]

67. Matsuzaki, T.; Matsumoto, S.; Kasai, T.; Yoshizawa, E.; Okamoto, S.; Yoshikawa, H.Y.; Taniguchi, H.; Takebe, T. Defining lineage-specific membrane fluidity signatures that regulate adhesion kinetics. Stem Cell Rep. 2018, 11, 852-860. [CrossRef] [PubMed]

68. Dokukin, M.E.; Guz, N.V.; Sokolov, I. Quantitative study of the elastic modulus of loosely attached cells in afm indentation experiments. Biophys. J. 2013, 104, 2123-2131. [CrossRef]

69. Ludwig, T.; Kirmse, R.; Poole, K.; Schwarz, U.S. Probing cellular microenvironments and tissue remodeling by atomic force microscopy. Pflügers Arch. Eur. J. Physiol. 2007, 456, 29-49. [CrossRef]

70. Sokolov, I.; Iyer, S.; Subba-Rao, V.; Gaikwad, R.M.; Woodworth, C.D. Detection of surface brush on biological cellsin vitrowith atomic force microscopy. Appl. Phys. Lett. 2007, 91, 023902. [CrossRef]

71. Rigato, A.; Rico, F.; Eghiaian, F.; Piel, M.; Scheuring, S. Atomic force microscopy mechanical mapping of micropatterned cells shows adhesion geometry-dependent mechanical response on local and global scales. ACS Nano 2015, 9, 5846-5856. [CrossRef]

72. Reis, A.; de Freitas, V. When polyphenols meet lipids: Challenges in membrane biophysics and opportunities in epithelial lipidomics. Food Chem. 2020, 333, 127509. [CrossRef] 